Abstracta Iranica Abstracta Iranica

Revue bibliographique pour le domaine irano-aryen

Volume 24 | 2003

Comptes rendus des publications de 2001

\title{
s.v. « Georgia. iii. Iranian elements in Georgian Art and Archaeology ». Eir X, 5, pp. 470-480.
}

\section{Rémy Boucharlat}

\section{(2) OpenEdition \\ 12 Journals}

\section{Édition électronique}

URL : http://journals.openedition.org/abstractairanica/34233

ISSN : 1961-960X

\section{Éditeur :}

CNRS (UMR 7528 Mondes iraniens et indiens), Éditions de l'IFRI

Édition imprimée

Date de publication : 15 mai 2003

ISSN : 0240-8910

\section{Référence électronique}

Rémy Boucharlat, « S.V. « Georgia. iii. Iranian elements in Georgian Art and Archaeology ». Eir X, 5, pp. 470-480. », Abstracta Iranica [En ligne], Volume 24 | 2003, document 33, mis en ligne le 05 janvier 2010, consulté le 25 septembre 2020. URL : http://journals.openedition.org/abstractairanica/34233

Ce document a été généré automatiquement le 25 septembre 2020

Tous droits réservés 


\title{
s.v. « Georgia. iii. Iranian elements in Georgian Art and Archaeology ».
} Eir X, 5, pp. 470-480.

\author{
Rémy Boucharlat
}

1 Il faut préciser que cet article traite des éléments comparables entre la Géorgie et le NO de l'Iran jusqu'au $4^{e} \mathrm{~s}$. de notre ère seulement, car selon l'A. «Iranian elements in ancient Georgian art and archaeology gradually ceased from the 4th century C.E. when Christianity became the official religion of the Georgian states » (p. 479). Un tel constat surprend lorsque l'on connaît la politique des Sassanides puis des différentes dynasties persanes disputant la Géorgie à Byzance d'abord, aux Ottomans ensuite. De gré ou de force, les Géorgiens ont souvent vu les Iraniens jusqu'au $18^{\mathrm{e}} \mathrm{s}$., et la présence de ces derniers a dû laisser des traces.

\section{INDEX}

Thèmes : 3.0. Généralités

\section{AUTEURS}

RÉMY BOUCHARLAT

CNRS - Lyon 